\title{
Corporate Sustainability Management and Environmental Ethics
}

Schuler, Douglas; Rasche, Andreas; Etzion, Dror; Newton, Lisa

Document Version

Accepted author manuscript

Published in:

Business Ethics Quarterly

DOI:

10.1017/beq.2016.80

Publication date:

2017

License

Unspecified

Citation for published version (APA):

Schuler, D., Rasche, A., Etzion, D., \& Newton, L. (2017). Corporate Sustainability Management and

Environmental Ethics. Business Ethics Quarterly, 27(2), 213-237. https://doi.org/10.1017/beq.2016.80

Link to publication in CBS Research Portal

\section{General rights}

Copyright and moral rights for the publications made accessible in the public portal are retained by the authors and/or other copyright owners and it is a condition of accessing publications that users recognise and abide by the legal requirements associated with these rights.

Take down policy

If you believe that this document breaches copyright please contact us (research.lib@cbs.dk) providing details, and we will remove access to the work immediately and investigate your claim. 


\section{Corporate Sustainability Management and Environmental Ethics}

\section{Douglas Schuler, Andreas Rasche, Dror Etzion, and Lisa Newton}

Journal article (Accepted version)

CITE: Corporate Sustainability Management and Environmental Ethics. / Schuler, Douglas; Rasche, Andreas; Etzion, Dror; Newton, Lisa. In: Business Ethics Quarterly, Vol. 27, №. 2, 2017, p. 213-237.

This article has been published in a revised form in Business Ethics Quarterly.

This version is free to view and download for private research and study only. Not for re-distribution, resale or use in derivative works. (ㄴ)17 Business Ethics Quarterly.

DOI: 10.1017/beq.2016.80

Uploaded to Research@CBS: November 2018 


\title{
CORPORATE SUSTAINABILITY MANAGEMENT AND ENVIRONMENTAL ETHICS: BETWEEN INSTRUMENTAL AND INTRINSIC REASONING
}

\author{
Douglas Schuler (contact author) \\ Jesse H. Jones Graduate School of Business, Rice University \\ schuler@rice.edu \\ Andreas Rasche \\ Copenhagen Business School \\ ara.ikl@.cbs.dk \\ Dror Etzion \\ Desautels Faculty of Management, McGill University \\ dror.etzion@mcgill.ca \\ Lisa Newton \\ Fairfield University \\ LHNewton@,fairfield.edu
}

\begin{abstract}
This article reviews four key orientations in environmental ethics that range from an instrumental understanding of sustainability to one that acknowledges the intrinsic value of sustainable behavior (i.e. sustainable resource use, conservation and preservation, rights-based perspectives, and deep ecology). It then shows that the current scholarly discourse around corporate sustainability management - as reflected in environment management (EM), corporate social responsibility (CSR), and corporate political activity (CPA) - mostly favors an instrumental perspective on sustainability. Sustainable business practices are viewed as anthropocentric and are conceptualized as a means to achieve competitive advantage. Based on these observations, we speculate about how corporate sustainability management might look like, if it applied ethical orientations that emphasize the intrinsic value of sustainable behavior. This discussion also includes an introduction to two articles in this issue focused on the role of the environmental manager and sustainability standards, both of which offer a path towards an intrinsic consideration of sustainability.
\end{abstract}

Keywords: corporate sustainability, environmental ethics, corporate social responsibility, environmental management, corporate political activity, sustainability standards

The AMJ Style Guide has been use for this manuscript. 


\section{INTRODUCTION}

Companies increasingly strategize and devote resources towards sustainability and the natural environment. Several factors appear to drive firms towards investing in organizational structures and practices that we call "corporate sustainability management," (Starik \& Kanashiro, 2013) including scientific insights about the relationship between human activities and ecosystems (Rockström et al., 2009); economic and social demands by consumers, employees, investors, and activists about how companies should approach the natural environment (Gardiner \& Thompson, 2017); and public policies that require or forbid business activities towards ecosystems (Abbott, 2012). Today's practices of corporate sustainability management are infused with ethical questions and dilemmas. For instance, the basic question: "What does it mean to be sustainable?" asks us to reflect on the end goal of sustainability and throws up normative questions. Asking such questions seems inevitable, because our conception of what sustainability is (and what it is not) has a significant impact on how we frame problems and solutions. Such questions and dilemmas touch environmental ethics: a philosophical discipline that is concerned with studying the moral relationship between the environment and humans (Brennan \& Lo, 2016). Yet, few scholarly contributions explicitly discuss the ethical underpinnings of corporate sustainability management (for an exception see DesJardins, 2016).

The purpose of this article is two-fold. The first purpose is to take stock of the ethical bases underlying corporate sustainability management. For this, we start by reviewing key perspectives on environmental ethics and integrate them into a framework consisting of four orientations: sustainable resource use, conservation and preservation, rights-based perspectives, and deep ecology. These orientations progress from an instrumental perspective (we value 
sustainability as a means to end to better serve human interests) to an intrinsic value approach (we value sustainability as end in itself). We then examine in how far these orientations are reflected in three organizational areas associated with corporate sustainability management: environmental management (EM), corporate social responsibility (CSR), and corporate political activity (CPA). While these areas are not exhaustive, they cover many of the strategies and daily practices that companies undertake in the name of sustainability. Our review reveals that corporate sustainability management - at present - implicitly adopts the instrumental and utility maximizing aspects that are consistent with the sustainable resource use and conservation orientations. In contrast, ethical orientations related to preservation, the rights of ecosystems and non-human animals, as well as deep ecology are underestimated.

The second purpose of the article is to show how corporate sustainability management might progress with regards to environmental ethics, if the underestimated orientations are taken more seriously. We speculate ways that companies might reconceive their ethical duties and practices in the EM, CSR, and CPA areas to incorporate more elements of ecosystem rights and ecological preservation. Furthermore, we introduce two organizational practices that are featured in the following two articles in this same $B E Q$ volume: (1) creating an active environmental manager position, who infuses environmental values and practices throughout the organization through his or her institutional work (Dahlmann \& Grosvold, 2017); and (2) consciously constructing places within organizations for debate and dissent about sustainability, called the license to critique (Christensen, Morsing, \& Thyssen, 2017). The practices advocated by these authors support, at least in part, an intrinsic value orientation and hence expand the ethical foundations of corporate sustainability management. 


\section{KEY ORIENTATIONS IN ENVIRONMENTAL ETHICS}

\section{Business Ethics and Environmental Protection}

When thinking about the ethical foundations of sustainable business practices, we enter a sub-field of philosophical inquiry that deals with normative questions around the relationship between human beings and nature: environmental ethics (Gardiner \& Thompson, 2017). As a field of scholarship, environmental ethics covers a variety of (a) theoretical concepts that frame the linkage between nature and humans and (b) central issues of concerns (e.g., deforestation and climate change). We therefore follow Brennan \& Lo (2016) who adopt a wide definition of the field and understand environmental ethics as a "discipline in philosophy that studies the moral relationship of human beings to, and also the value and moral status of, the environment and its non-human contents." The discussion of sustainability's ethical foundations can be understood as being part and parcel of this field.

Contemporary environmental ethics emerged as a discipline in the 1970s. From this time onwards a number of studies have concluded that business can be conducted in a way that is both safe for the environment and profitable for itself. As early as 1990, the Center for Business Ethics at Bentley College held a conference on The Corporation, Ethics, and the Environment (Hoffman, Frederick, \& Petry, 1990). The late 1990s saw the publication of John Elkington's (1998) Cannibals With Forks (which introduced the notion of the Triple Bottom Line), David Roodman's (1998) The Natural Wealth of Nations, and the game-changing Natural Capitalism:

Creating the Next Industrial Revolution, by Paul Hawken, Amory Lovins and L. Hunter Lovins (1999). The opening decades of the $21^{\text {st }}$ century have seen the publication of more comprehensive thinking on taming business to protect the natural environment. Philosophers 
Mark Sagoff (2004), Lisa Newton (2005), and Joseph DesJardins (2007) from backgrounds in ethics and business ethics, produced monographs covering what is now considered familiar ground. More recently, newer voices joined: William McDonough, a pioneering environmental architect, teamed up with industrial designer Michael Braungart to reconceptualize manufacturing (McDonough \& Braungart, 2002, 2013). The measures they urge-finding substitutes for hazardous materials, for instance-have not been widely adopted, because, as McDonough and Braungart (2013: 74) point out, "finding a substitute takes work and time," neither of which can be justified to shareholders when the results are distant and uncertain.

Sustainability has emerged as a topic within environmental ethics (Audi, 2010; DesJardins, 2016; Nelson \& Vucetich, 2012). Many people have turned to the popularized definition in the Brundtland Report, which defines sustainable development as being about meeting "the needs of the present without compromising the ability of future generations to meet their own needs." (World Commission on Environment and Development, 1987: 54) Although the Report has been criticized for being vague and offering a "catch-all" treatment of sustainability to bridge conflicting political interests (Hempel, 2012), many authors have used it as a starting point for exploring the ethical foundations of sustainability (see e.g., Dobson, 1998). From the perspective of environmental ethics, the Brundtland definition highlighted two key concepts (Brennan \& Lo, 2016): (1) the concept of needs and the obligation to prioritize the needs of those who live in poverty and (2) the notion that there are limitations on the environment's ability to meet future and present needs, especially when considering that some of these limitations are imposed by the state of technology and social organization. Of course, the Brundtland definition is but one definition. We use Sharma's (2014) definition of sustainability 
as an anchor point. He understands sustainability as the "resilience and the longevity of our ecosystems (which includes minerals, vegetation, oceans, atmosphere, climate, water bodies, and biodiversity), society (which includes culture, languages, and quality of life) and economy." (Sharma, 2014: 1-2) This definition explicitly covers different dimensions of sustainability and hence shows that the concept is not limited to environmental aspects, but equally relates to social and economic issues. The focus of sustainability is not just "living things" but the whole community of life. He acknowledges that the condition as described may be difficult to achieve- but still be eminently worth working for.

\section{Orientations in Environmental Ethics: Instrumental and Intrinsic Value}

In order to understand the full spectrum of possible orientations within environmental ethics, we now review four key orientations in the literature on environmental ethics. Although by no means an exhaustive list of contributions, these orientations can be seen as progressive categories, from an instrumental value perspective (most prevalent in sustainable resource use and conservation orientations) that puts few limits on the human uses of the natural world to an intrinsic value perspective (most prevalent in preservation, rights-based and deep ecology orientations) that puts few limits on our obligations to protect that world (see Table 1). Do we value ecosystems as a means to further some other ends (e.g. profit), or do we value ecosystems as ends in themselves regardless of their usefulness as means to serve other ends? Instrumental perspectives on environmental ethics are usually anthropocentric (i.e. human-centered) in that their focus is on sustaining human well-being and maximizing social welfare throughout time (Neumeyer, 2003). Such utilitarian reasoning often assigns greater value to human beings than to non-human beings; the protection of human interests at the expense of non-human interests is 
almost always justified. We may have responsibilities towards ecosystems, but these are contingent upon that our treatment of ecosystems serves certain human values (Taylor, 1981).

The instrumental/intrinsic value distinction relates to some degree to the discussion of whether firms' sustainability programs should aim at maximizing utility for society and themselves. Instrumental reasoning would suggest that sustainability is desirable, because it maximizes social welfare and, when applied to the corporate context (e.g. through CSR), also shareholder wealth (for a critique of the link between shareholder wealth and social welfare see Jones \& Felps, 2013). Intrinsic value reasoning does not simply reach beyond such utility maximization arguments (be it for society or the firm); it asks us to view sustainability as an end it itself. While instrumental value is always derived from the value of something else (e.g., welfare, profit), intrinsic value is not conditional (Sandler, 2012).

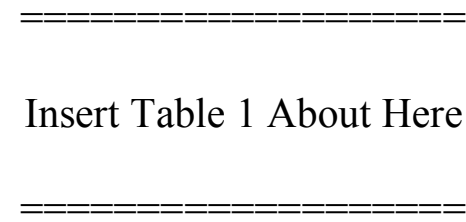

Sustainable Resource Use. For most of human history, our orientation to nature has been one of profitable use: If there are natural resources available, that we can turn to profitable use, we will do that. Not until the end of the $19^{\text {th }}$ century did it occur to the United States that this procedure was unsustainable even in the short term. It was Gifford Pinchot, friend of President Theodore Roosevelt and founder of the Yale School of Forestry, who talked Congress into passing the Forest Management Act of 1897, setting aside National Forests as reserves for lumber (Newton, 2013). The first move in environmental protection, then, on the national scene, 
exemplified the Brundtland Report's understanding of sustainable development (see above). The report understood sustainability as a restriction on profitable use. We can use any natural resources for our profit, but we must do so in such measure as to keep such use possible into the indefinite future.

Many scholars have discussed the ethical foundations of the sustainable resource use orientation (see e.g., Angelsen, 2011; DesJardins, 2016; Langhelle, 1999, 2000). Few of these discussions reach beyond an instrumental understanding of the human-environment relationship, most emphasize that sustainable resource use is a means to serve human well-being. Dobson (1998), for instance, identified three ways in which distributive justice and sustainable resource use are related. Firstly, the natural environment is seen in a rather instrumental way, as something to be distributed among humans. This makes the natural environment the object of a justice discourse and the basic question would be how a fair distribution of natural capital according to universal needs would look like. Secondly, justice can be seen as functional for sustainability: without a certain level of justice within a society it is difficult to achieve longterm environmental protection. Such an understanding points to win-win situations between justice and environmental protection, for instance when reductions in poverty levels decreases deforestation. Third, one can accept that the natural environment itself is intrinsically worthy of protection. Here, the environment is seen as a recipient of justice regardless of human needs.

Other scholars have adopted a utilitarian perspective on sustainable resource use. For instance, the triple-bottom-line is sometimes interpreted in a utilitarian and anthropocentric manner. Looking at three bottom lines, we are asked: "how can we play off competing costs of 
sustaining one versus the others, so as to maximize 'net human preferences'?" (Abney, 2004: 27). Similarly, the work of Peter Singer (1993) has adopted a utilitarian perspective on sustainable resource use. Singer argued that all animals, which can experience pleasure and pain, need to be taken into consideration when morally assessing an action. However, non-sentient objects of the environment (e.g., rivers and mountains) hold no intrinsic value in Singer's theory and hence only serve an instrumental value of being relevant when satisfying the need of sentient beings (see also Brennan \& Lo, 2016).

Conservation and Preservation. While preservationists believe that there is an intrinsic value in the natural world and hence follow a non-anthropocentric perspective (e.g., because other species are assigned a certain moral status; DesJardins, 2016: 126), conservationists focus on environmental protection out of enlightened self-interest, conserving resources for later use by humans (see e.g., Fiedler \& Jain, 1992; Neumeyer, 2003; North, 1987). The difference between both approaches becomes obvious when looking at the treatment of forests in the US. By the opening of the $20^{\text {th }}$ century, the country had recognized that there can be human needs other than economic profit; as early as 1872 and the founding of Yellowstone National Park, there was an understanding not only that natural areas are beautiful, but that such beauty was a national asset and should be saved for deeper human purposes: recreation, spiritual renewal, physical health, and education. This beauty should be kept and protected and made accessible to all Americans; this conviction is the basis of the conservationist movement. The possible conflict between saving the beauty of these wonderful places and ensuring accessibility for all Americans became evident with the advent of the automobile, when in a very short period of time enough Americans descended on the Parks to become their largest problem. No reason could be found 
for protecting the Parks from the citizens they were meant to serve, but clearly someone had to keep the entirety of the American heritage of wild nature from being loved to death. Recognizing the problem, in 1964 US Congress created a new designation, the Wilderness Area, where the ruling motive would not be service to current citizens, but preservation for the distant future. The argument prevailed, that intact forests, tracts of wilderness, are valuable in themselves, and should be preserved forever wild. Why? For no human purpose, save that we recognize that intrinsic value. Incidentally, included in this value was, for the first time, recognition of the "services" that natural areas provide: stabilizing watersheds, cleaning the air, and protecting the natural species that live within them. The discussion by Frank et al. (2000) shows that a number of other countries also moved towards preservation by reinterpreting the role of their respective national parks (e.g., Australia, Canada, and New Zealand).

Rights-Based Perspectives. A number of scholars have understood environmental ethics from a rights-based perspective (e.g., Bradley, 2006; McShane, 2014; North, 1987). Often based on deontological ethics, scholars have argued that single species or also entire ecosystems enjoy rights that need to be respected. One important strand of literature deals with animal rights. The basic claim is that non-human animals experience pain just as we do, and enjoy those activities that are natural to their species. Hence, they should not be hurt, frightened, or confined in such a way as to thwart natural activity. They have rights because they need to be valued for what they are. The animal rights movement has immediate bearing on the food industry, especially on the handling of livestock: the movement wants an end to many of the practices associated with the confinement, feeding, and slaughter of animals, especially the beef cattle that we raise for food (e.g., Singer, 1975; Francione \& Carlton, 2015; Waldau, 2011). At many points during animal 
rights campaigns, the moral reasoning employed is confusing: are they asking merely for gentler and less painful methods of keeping and harvesting the animals, an extension of our present strictures on "cruelty to animals"? Or, are they asking that such animals be attributed rights, on an analogy with intellectually impaired human beings, who have a right to legal representation to ensure that adequate provision is made for them (Newton \& Dillingham, 2002)? Authors in this movement have adopted both approaches, and often sliding from one to the other.

Other scholars have adopted a perspective that focuses on ecosystem rights (often referred to as ecocentrism). It is not the individual animal, or the species, that must be protected, but the intact ecosystem, a community of biological members (animals, birds, fish, insects, grasses and trees) and the rocks, water, and earth that support their lives. As Aldo Leopold (1949: 224-225) put it, "A thing is right when it tends to preserve the integrity, stability, and beauty of the biotic community. It is wrong when it tends otherwise." Understood in this way, the entire ecosystem becomes the object of moral concern. Taylor (1981), for instance, outlined a rights-based theory of ecosystems, which emphasized the intrinsic value of all members of such systems (including humans). According to Taylor (1981), such a perspective needs to see "the whole natural order of the Earth's biosphere as a complex but unified web of interconnected organisms, objects, and events." (p. 209). It is thus the moral duty to respect the integrity of the entire ecosystem.

Deep Ecology. Rights-based perspectives require humans to protect ecosystems with only a few exceptions. Deep ecology further extends this line of thinking by emphasizing humans' full dependence on nature. As humans depend on nature, they have no right to redirect 
its processes for their own use. Much of the deep ecology literature relates to the work of Arne Næss $(1973,1989)$, even though there is no integrated and unified conception (for a critical review see Sylvan, 1985). Næss contrasts what he calls a "shallow ecology movement" from a “deep, long-range ecology movement." While the shallow movement is primarily aimed at protecting the affluence of people in developed countries, the deep ecology movement departs from biospheric egalitarianism. Such egalitarianism suggests that we value all living things equally and independent of their usefulness to others (Brennan \& Lo, 2016). It also rejects a focus on individual species and adopts a "total-field image." Such an image sees all organisms (human or otherwise) as knots in a larger biospherical net. Næss (1973) conceptualized the identity of all living things as depending on the relationships between different organisms in this net. No organism exists for itself. If humans start to conceptualize themselves as being embedded in and dependent upon other species, they will start to take better care of them.

Deep ecology also adds a political element to the discussion. Næss (1973) advocated an "anti-class posture" that rejects the exploitation of man by man and also of nature by man. Dominating social structures by any group are reprobated, mostly because deep ecology has a concern for diversity (e.g., cultural traditions that are non-Western) as well as cooperation. The deep ecology movement also criticized the negative social and environmental effects of globalization and encouraged local autonomy (e.g., in terms of production). Deep ecology is arguably a perspective on environmental ethics that places almost no limits on our obligations to protect ecosystems. It was criticized in a variety of ways. Some argued that it is hard to understand how termites or bacteria could have interests that are of moral relevance. Grey (1993: 466), for instance, asks: "[S]hould we be concerned about the fate of the planet several billion 
years hence, or about the welfare of bacteria? I think not." Others have argued that deep ecology promotes a utopian vision (Anker \& Witoszek, 1998) and that some of its principles are unlikely to work in the contexts of developing and emerging countries (Guha, 1989).

\section{CORPORATE SUSTAINABILITY MANAGEMENT AND ETHICS:}

\section{WHERE IT STANDS TODAY}

We continue from the ethical considerations about how humans might consider sustainability to the scholarship about how companies approach corporate sustainability management. Although there is not a unified scholarly discourse around corporate sustainability management, much of the debate about how sustainable business practices should be implemented in organizations has been carried out in three interrelated discourses: environmental management (EM), corporate social (including environmental) responsibility (CSR), and corporate political activity (CPA). Our review shows that most "mainstream" discussions within EM, CSR and CPA adopt an instrumental view on sustainability (see also Scherer \& Palazzo, 2011). Corporate sustainability management is conducted out of enlightened self-interest, in that sustainability's task is to find the best means (e.g., minimize material losses in manufacturing or lobby for new regulations) of using natural resources to achieve company goals of profitability. Ethical orientations that emphasize the intrinsic value of sustainability, like environmental preservation or ecosystem rights, which would move the discourse beyond viewing the humanenvironment relationship in instrumental terms, do not feature much in current scholarly work. While various scholars have pointed to the limits of a utilitarian view on assessing corporate goals (Jones \& Felps, 2013), few have explicitly related the intrinsic value orientation to the discussion of corporate sustainability (see Luke, 2002 for an exception). 


\section{Environmental Management}

Research on organizations and the natural environment began in earnest in the early 1990s with a special issue of Academy of Management Review followed in 2000 with a special issue of Academy of Management Journal. Some of this initial work was quite ambitious, positioning the pursuit of environmental goals as a key endeavor for businesses (Gladwin, Kennelly, \& Krause, 1995; Starik \& Rands, 1995). Notwithstanding, the major thrust of research in the past two decades has revolved around the linkage between corporate environmental performance and corporate financial performance. In addition to empirical tests of the validity of this correlation (Orlitzky, Schmidt, \& Rynes, 2003; Waddock \& Graves, 1997), researchers have proposed various explanations as to why this link might actually be plausible. Explanations include lean manufacturing and waste reduction as a progenitor of cost-cutting (King \& Lenox, 2001, 2002); revenue gains through innovation (Bansal, 2005; Berrone, Fosfuri, Gelabert, \& Gomez-Mejia, 2013); capacity to effectively predict and address stakeholder concerns and social pressures (Hart \& Sharma, 2004; Sharma \& Henriques, 2005; Sharma \& Vredenburg, 1998); and reduced risk (Sharfman \& Fernando, 2008). An influential theory is the natural resource based view of the firm (Hart, 1995), arguing that firms' three key strategic capabilities - pollution prevention, product stewardship, and sustainable development - lead to superior environmental and economic performance (Russo \& Fouts, 1997). This focus already shows that much of the EM literature is framed in a rather instrumental way: ecosystems are protected because it may enhance firm performance or maximize social welfare. 
Another central strand of EM research examines the external safeguards that can align corporate activity with environmental protection. These include regulation, which Michael Porter famously argued could make firms both green and competitive (Porter \& van der Linde, 1995a, b), institutions of industry self-regulation (Hoffman, 1999), various standards such as ISO 14001 (Potoski \& Prakash, 2005; Wijen, 2014), and environmental ratings and ranking by analysts (Delmas, Etzion, \& Nairn-Birch, 2013). The underlying normative orientation in this literature remains an instrumental one. For instance, research on environmental standards like ISO 14001 has mostly discussed the performance implications of standard adoption. The achievement of sustainability becomes a means to an end (i.e. profit). A number of studies have also explored efforts to constrain corporate environmental impacts. This literature typically examines the influence of different groups that claim to represent the environment, rather than the natural environment itself (Prasad \& Elmes, 2005). This includes activists (Bertels, Hoffman, \& DeJordy, 2014; Hoffman, 2001; Maguire \& Hardy, 2009), local communities (Kassinis \& Vafeas, 2006; Russo, 2010), consumers (Sandhu, Ozanne, Smallman, \& Cullen, 2010), and governments. While some of this literature acknowledges the role of ideologies that reach beyond a market-based logic (e.g. activists' collective action), other groups are discussed from a more instrumental perspective (e.g., related to consumer choice).

The EM corpus follows by and large the instrumental interpretation of the sustainable resource use and conservation orientations. The framing is that a win-win is attainable: utility (healthy profits and a healthy environment) can be achieved via skilled environmental management without trampling on the rights of ecosystems, humans, or non-human animals. Environmental performance is seen as one element of overall corporate performance, and can be 
measured in the short or long-run (although long-run is difficult). According to EM, companies should judiciously guide their own resources towards sustainability programs, while overinvestment is portrayed as counter-effective (Barnett \& Salomon, 2012) and normatively bad because it fails to promote the primacy of the shareholders. To be fair, however, not all research on environmental management can be characterized this way. Several scholars have drawn attention to the inherently normative aspect of time perception - i.e., short-termism versus longtermism in shaping corporate environmental behavior (see e.g., Slawinski \& Bansal, 2012, 2015). Also, some scholars have recently begun more forcefully drawing attention to the necessity of tighter linkages between sustainability science, planetary boundaries, and corporate impacts (Hoffman \& Jennings, 2015; Whiteman, Walker, \& Perego, 2013).

\section{Corporate Social Responsibility}

We understand CSR as the operationalization of a firm's responsibilities towards its stakeholders as well as the natural environment (Waddock, 2008). Much of the literature distinguishes between market stakeholders (e.g., customers, employees, and investors) versus nonmarket stakeholders (e.g., governments, communities impacted by the firm, and the natural environment) (Baron, 1995; Starik, 1995). While CSR scholars have long argued for a variety of normative approaches for a firm's managers to take towards stakeholders (see e.g., Garriga \& Melé, 2004; Windsor, 2006), most theorizing in the CSR domain refers to an economic and instrumental approach (Scherer \& Palazzo, 2011). It views social justice from a utilitarian perspective as a strategic tool to realize economic objectives and to create wealth (McWilliams \& Siegel, 2001). The satisfaction of "salient" stakeholder interests is seen as contributing to shareholder wealth (Mitchell, Agle, Wood, 1997). Even corporate philanthropy is viewed in a 
strategic way - that is, as a tool to meet firms' fiduciary responsibilities (Porter \& Kramer, 2002; critically see Blair, 2015). While facets of the interrelationship between the corporation and society include duties to not intentionally harm and to follow the laws and customs, the anchor is to choose CSR activities that promote the competitiveness of the firm, either by enhancing value chain efficiencies or growing the firm's market power (Porter \& Kramer, 2006). This economic view on CSR promotes the business case to sustain CSR and limits a corporation's responsibilities to those cases where shared value can be achieved (Porter \& Kramer, 2011). The dominant instrumental approach to CSR argues for adopting welfare-based distributive principles and thus views other distributive concerns (e.g., serving the community's least advantaged or establishing equality) not as a primary problem of CSR.

A number of other normative approaches challenge this instrumental orientation. Here, we mention three alternatives, although this is by no means a complete list. First, some scholars have highlighted the normative core of stakeholder theory (see the summary by Garriga \& Melé, 2004). Donaldson and Preston (1995: 66-67), for instance, have suggested (a) that stakeholders often have legitimate interests in a corporation without the corporation having any interest in them and (b) stakeholder interests are of intrinsic value in the sense that relevant constituents need to be considered for their own sake (including the natural environment). Considering the intrinsic value of stakeholders allows for reaching beyond a purely anthropocentric perspective on sustainability, at least when the natural environment is viewed as a stakeholder (Starik, 1995). Second, a number of scholars have outlined a political approach to CSR (see e.g., Scherer, Rasche, Palazzo, \& Spicer, 2016). Political CSR rests on the recognition of the universal nature of rights and the communicative process by which such rights are defined. As corporations often 
administer these rights due to their political role, even in cases where there is no instrumental motivation, political CSR reaches beyond the utilitarian logic of instrumental reasoning. Corporations' legitimacy is deliberatively constructed (Scott, 2001) and hence can include representatives of non-human entities and mute others (e.g., future generations). Lastly, some proponents argue that the common good of society should act as the reference point for CSR (Velasquez, 1992). Such a perspective is concerned with distributive justice. However, it does not take the firm as a reference point but rather emphasizes that individual firms have to contribute to the common good of society, not only by creating wealth but also by ensuring equal opportunities and respecting fundamental universal rights. The common good approach would thus consider justice in light of all members of society.

\section{Corporate Political Activity}

The concern of firms to maximize their influence with governmental officials to gain favorable policies dominates the CPA approach. Rarely reflecting upon the morality of influence actions (for a recent exception, see Arnold, 2016), the CPA approach promotes firms to seek ways of encouraging government officials to create policies that benefit their industries and businesses (Fremeth \& Richter, 2011; Haley \& Schuler, 2011; Henisz \& Zelner, 2012; Schuler, Rehbein, \& Cramer, 2002). For example, intending to influence public officials to support their policy interests, firms might use lobbyists to push their agenda, hire persons with personal ties to government officials or the office (Hillman, 2005), support the campaigns of sympathetic legislators, and mobilize other stakeholders towards political action. CPA's instrumental character mostly views political action as a means to protect firms from policy threats (e.g., 
unfavorable regulation), business threats (e.g., "unfair" imports), or to leverage their relationship with government (Rasche, 2015).

Much of the literature views CPA through the lens of interest group pluralism (Dahl, 1959; Berry, 1999), which is consistent with a utilitarian principle. With the government providing the forum, such as a legislative committee, administrative agency, or court of law, interested parties have the freedom and the right to advocate their position on a particular issue in front of government officials. While at a single moment power is not equally distributed across such interested parties, pluralism assumes that over time the various interest groups will have opportunities to exercise voice and have their positions reflected in the laws and rulings of the state (Dahl, 1959). As more interest groups and citizens participate and voice, as "people stand up" (Rousseau, 1762), public officials are more likely to create good (over bad) laws that serve the public good (Mill, 1861, c.f., Christiano, 2006). In principle, pluralism supports rights-based environmental ethics, at least in part, because its advocates will participate and public officials will consider their claims in making rules. Over time, public officials will aim to create social consensus about that particular issue and to adopt laws that best serve society. However, in practice, interest group pluralism suffers from at least three defects, each of which contributes to making it fall short of achieving policies that consider the intrinsic value of sustainable business.

1. Certain groups are more able to produce the type of information necessary for the public policy process. In the United States, for example, it is well-documented that the agency rule-making process is very slow (about 10 years) because bureaucrats in such agencies painstakingly seek information from expert sources 
(West, 2009). Furthermore, business interests may be able to provide disinformation (Arnold, 2016) in more powerful ways than non-business interests. For example, Exxon-Mobil funded research that allowed it to put out inaccurate information about the effects of burning hydrocarbons on the greenhouse gases and climate change (McKibben, 2015). Thus, policymakers oftentimes lack complete information about ecological issues, retarding their ability to craft public policies about sustainability.

2. Because it is costly to participate in public policy, not all organizations do so. Many companies, particularly large ones, are able to afford information gathering, dissemination (i.e., through professional lobbyists), stakeholder mobilization (i.e., through employees), and other activities. Furthermore, companies are oftentimes members of trade associations for competitive reasons allowing for information pooling, lobbying, and related government activities at low marginal costs (Olson, 1971). However, many other interests, including ecological ones, may not be able to afford to do at the same levels. As such, business interests participate more frequently than other types of groups (Olson, 1971), decreasing the likelihood that public policies about the environment will reflect ecological and other social justice interests.

3. Business has many social advantages over non-business interest groups. Lindblom (1977) argued that public officials, particularly elected ones, prefer business interests over non-business interests such as environmental groups, because of 
their ability to generate employment (salaries), products and services; in this manner, business is privileged with public officials over all other groups. Other scholars showed that elected officials are tied to many monied interests dominated by businesses - from both social backgrounds (i.e., common schooling) and through the financing of elections (Clawson, Neustadtl, and Weller, 1998). As a result, public officials are likely to favor commercial over ecological interests in making environmental policies.

\section{MOVING TOWARDS AN "INTRINSIC VALUE" ORIENTATION IN CORPORATE SUSTAINABILITY MANAGEMENT}

This section suggests ways to move towards a less instrumental understanding of ethics in corporate sustainability management. We discuss how certain organizational practices might look like with an expanded ethical vista. More precisely, we speculate upon how EM, CSR, and CPA might be extended to better incorporate those ethical orientations that emphasize the intrinsic value of sustainable behavior. We also introduce two so far undervalued ways to better integrate the intrinsic value perspective into relevant discourses - the role of the environmental manager (contributing to the EM discourse) and the license to critique approach towards sustainability standards (contributing to the CSR discourse). Both discussions are covered in the two following articles in this $B E Q$ issue.

\section{EM and Intrinsic Value Orientations}

EM practices are not, prima facie, incongruent with an intrinsic value orientation in environmental ethics. In practice, however, environmental management practices as pursued in 
most corporations fall far short of requirements to attain any semblance of a sustainable planet. And yet, some developments are creating entry points that may perhaps lead to a more ethical, "sustaincentric" (Gladwin et al., 1995) paradigm. Two recent developments are worth considering. A first development eschews the free market perspective where environmental management is currently entrenched, in which each corporation is perceived as a distinct autonomous entity, typically a corporate person. In this legal frame, a corporation, like a human individual, is expected to conduct itself in a lawful manner. Yet this conceptualization of a bounded, discrete, corporate entity is increasingly questioned in the EM literature (see also Blair, 2015). Large corporations are under pressure from activists, governments, and others to take into account their upstream and downstream impacts and hence to adopt a systems perspective. We see corporations pursuing "net-green" approaches which incorporate not only full value chain analyses of environmental impacts, but also rebound effects and other unintended consequences (Zink \& Geyer, 2016). Such a view recognizes that, much like dominant organisms in ecosystems, powerful organizations that rampantly externalize their costs and other negative impacts can destabilize complex systems. This makes the negative consequences of corporate behavior more visible when assessing the moral nature of actions. Thus the rights of ecosystems and non-human organisms can be considered better, as they (a) can be judged in more detail and also with more contextualized information, and (b) do not escape the attention of decisionmakers anymore.

A second way through which environmental ethics can wormhole its way into corporate contexts is through the notion of risk - a concept increasingly tethered to that of sustainability in the worlds of practice and academic theory (World Economic Forum, 2016). More and more 
companies perceive climate change as a losing proposition, made salient through anticipated present (not future) and material (monetarily sizable) impacts, ranging from the cost of shoring up mines because of recurrent flooding to lost productivity because of black-outs in days of extreme heat (CDP, 2014). While such thinking links risk to instrumental ethical orientations (i.e., risk is minimized to protect corporate profits), risk can also assume more of an ecological systemic element, consistent with environmental preservation. Understood in this way, risk needs to be minimized because nature has an intrinsic value and destroying this value would be risky (e.g., because we assign certain non-human species a moral status; Sandler, 2012). Such a nonanthropocentric perspective on risk opens the EM discourse towards broader thinking about humans and non-humans place in a natural system.

Perhaps the greatest benefit in harnessing the risk and systems approach to EM research is that these ideas provide significant interpretive flexibility (Ferraro, Etzion, \& Gehman, 2015) and hence can be coupled to multiple ethical orientations. Corporate risk and societal risk are easily connected. Large beverage makers (Unilever), furniture purveyors (IKEA) and apparel manufacturers (Levi's) have recognized that multinational companies cannot exist in a world without tea trees, forests, or water (Gelles, 2015; Gunther, 2016). Concepts like "risk" and "systems" are sufficiently broad to move beyond instrumental perspectives on EM and to highlight the intrinsic value of the human-environment link.

\section{The Environmental Manager and the Role of Institutional Work}

In this special section, Dahlmann and Grosvold (2017) focus upon the role of the environmental manager as the linchpin within the organization to shape and promote corporate 
sustainability. The contribution of their approach is to drill deeply within the organization to the individual within the company, whom they call the "Environmental Manager" (although companies have different titles for this post), charged with developing and implementing corporate sustainability policies. Instead of looking at corporate sustainability management at the organizational level, the authors study those managers who work at lower levels of the firm "where much of the mundane work of environmental engagement occurs" (p. XX). Dahlmann and Grosvold view environmental managers as agents doing institutional work - i.e. the "purposive action aimed at creating, maintaining, and disrupting institutions" (Lawrence and Suddaby, 2006: 215). The authors correctly identify that the environmental manager's interpretation of sustainability and his or her daily and weekly communications critically shape how others within the company develop and implement various policies and programs.

From their interviews of environmental managers of 55 British companies, the authors identify two prominent logics that companies applied to sustainability. From the interviews, the market logic - consistent with the instrumental ethical orientation - was overwhelmingly dominant and central. As such, most environmental managers saw their job as staying within a "philosophy of convenience" and "managing sustainability" to avoid operational disruptions, match commercial and institutional desires of customers (i.e., ISO certification) and regulators, mitigate risks, improve efficiencies and lower costs, and otherwise best serve the firm's overall financial interests. However, Dahlmann and Grosvold also discovered that some environmental managers held an ecological logic more in line with what we described as an intrinsic value orientation. This ecological logic became more dominant over time. For example, environmental managers holding the environmental logic felt morally obligated "to protect the natural 
environment or otherwise behave as responsible businesses" (p. XX) and that doing so gave them a great sense of pride.

Another important contribution of this study is the finding that environmental managers act as "agents" for sustainability, planting the seeds of sustainability in other parts of the organization. In some of the companies the locus of stewardship and ownership of sustainability practices migrated from the environmental manager (and, if there was one, his or her department) into other departments and individuals within the firm. In these instances, the institutional work of the environmental manager acted similarly to a contagion in an organism - from a localized origin sustainability became more widespread within the company. To show how sustainability is enacted within companies, the authors identify three categories of institutional work: creation, maintenance, and disruption. Creation involves how the environmental manager frames organizational activity around sustainability: could sustainability be intimately integrated within the existing ways of doing business ("strategic creation"), could it be relatively easily added to a "minor" activity ("opportunistic creation"), or could it be considered only if slack resources existed ("conditional creation"). Environmental managers using maintenance tried to shape the existing structures within the company, such as management committees, and outside of it, such as regulatory bodies and rules, to align such structures to the company's sustainability activities. Finally, some environmental managers engaged in accelerating disruption by pursuing novel approaches to sustainability, as the authors write, "beyond... turning off the lights." (p. XX). The paper shows that environmental managers work with different (and sometimes competing) ethical orientations and that these orientations shape how sustainability activities are enacted over time. 


\section{CSR and Intrinsic Value Orientations}

What would it mean for CSR to move beyond an instrumental orientation? Scherer \& Palazzo (2011) argue that the current dominant instrumental approach rests on certain premises (e.g., firms have to maximize profits and societal responsibilities can only be assumed if they support the long-term value of the firm). Moving beyond these premises would mean to abandon the organizational-centric utility maximizing framework and replacing it with other ethical concerns, such as social justice (Bowie, 1991) and environmental rights (Bradley, 2006; McShane, 2014). For example, affirming an instrumental approach of CSR, mining companies sponsoring CSR activities in remote areas near their sites have been shown to benefit socially and politically (Henisz, Dorobantu, \& Nartney, 2014). A social justice approach might focus upon supporting the development of human skills for those living in such areas that are appropriate for that community (Rogers, 2003), even if they are not preferred by the present political or business elites. Companies might also allocate CSR to support the common pool resources (e.g. forests), even if they are unable to receive "credit" for such expenditures. Changing this orientation tosses CSR back to its "philanthropy" and "discretionary" (Carroll, 1979) roles, where social expenditures can be used to promote social justice, rights, and commons concerns without regard for how it might promote the company's bottom line.

Moving beyond the instrumental approach can also mean to adopt a more political understanding of CSR (Scherer \& Palazzo, 2011). Political CSR emphasizes that firms are often turned into political actors, because they provide public goods and hamper public bads in cases where governments are either unwilling or unable to fulfill this role (Scherer et al., 2016). Firms 
do not accept CSR because it helps their competitive position, but because they are forced to assume an active role in socio-economic governance. Firms' political role is often most obvious when looking at their participation in sustainability standards (e.g., UN Global Compact, the Global Reporting Initiative). The discussion of these standards within CSR can be extended when considering ecosystem rights approaches as well as environmental preservation. So far, most of the discussion views standards still in instrumental terms (e.g., firms join the UN Global Compact because it improves their financial bottom line; Rasche, 2009). Considering that sustainability can also be something that is valued intrinsically and "for its own sake" opens up new perspectives on standards. For instance, smaller and family-owned firms may adopt such standards because they feel a moral obligation towards nature and society (which resembles a rights-based approach towards ecosystems; Baumann-Pauly et al., 2013). Also, some standards may allow firms to see how different eco (and non-eco) systems interact, which follows deep ecology reasoning and helps them to understand how the identity of all living things depends on the relationships between different organisms.

\section{Sustainability Standards and the Organizational License to Critique}

The article by Christensen, Morsing, and Thyssen (2017) offers a fresh look at the communicative constitution of sustainability standards. Christensen and co-authors convincingly argue that many standards operate in contexts that support communicative closure - that is, a state in which the adoption of a standard leads to the termination of reflection and debate about what exactly sustainability means and implies. The authors view such closure as dysfunctional, because sustainability challenges are dynamic and hence change across time and context (Rockström et al., 2009). If standards are reduced to compliance tools, it is unlikely that adopters 
will be able to use them as a framework to make sense of novel sustainability problems. The authors identify a number of sources that contribute to the closure of sustainability standards. For instance, some standards have a built-in orientation towards the past (i.e., the time when the standard was formulated) and hence create pressures to align past commitments with current practices. Other standards are formulated in a way that promotes attention to specific details within adopting organizations; in these situations standards promote a "tick-the-box" attitude and impede necessary discussions about the very meaning of sustainability.

To overcome such communicative closure, the authors propose a new approach towards sustainability standards: standards as a license to critique. Such an approach "calls for organizations to deliberately sensitize themselves to local insights and experiences about sustainability issues while actively seeking to transform such insights and experiences into improved sustainability practices." (p. XX) This approach asks adopters to use the standard as a vehicle to promote discussions about what sustainability is (and what it is not) in the context of the organization. A license to critique develops our theoretical understanding of sustainability standards; it emphasizes that communication about standards continuously creates organizational reality. Standards are realized in communication. Such a theoretical understanding differs from the widespread assumption that communication about standards constitutes a separate organizational sphere. Rather, the authors make us aware that communication about what a standard means in a specific context shapes current and future organizational practices. Theoretically, they base this argument on the communicative constitution of organizations (CCO) perspective. CCO scholars emphasize that organizations do not consist of communication, but that organizations are constantly constituted in and through communication 
(see e.g., Schoeneborn et al., 2014). This perspective conceptualizes sustainability standards as sensitizing devices vis-à-vis specific sustainability issues.

The license to critique approach is a unique contribution to the discussion of standards for corporate responsibility and sustainability (Gilbert, Rasche, \& Waddock, 2011; Rasche \& Esser, 2006). It uncovers that standards serve as a basis for critique and contestation around sustainability issues within corporations. Standards help to explore the ethical underpinnings of corporate practices, as they can open up a communicative space in which questions around right and wrong can be debated. Christensen et al.'s article shows that firms do not passively receive sustainability standards. In a license to critique perspective, standards are enacted through participation of their employees. Contrary to Habermasian perspectives on standards (Gilbert \& Rasche, 2007), participation does not necessarily imply consensus and agreement. Rather, participation is explorative and aim to uncover new solutions, aspirations, and ideas. Understood in this way, standards can help adopting organizations to clarify the moral foundations of sustainability. They are not just compliance instruments, but they offer a platform for communicatively exploring the ethical underpinnings of sustainability. As such, the license to critique approach allows for the introduction of radically different ethical orientations into the organization, such as ecosystem rights and deep ecology, and hence helps to move beyond an instrumental perspective.

\section{CPA and Intrinsic Value Orientations}

A company approaching CPA with an intrinsic view of the environment needs to consider the effects of its actions beyond on its own long-term financial livelihood. As such, the 
most critical deviation from present practices is for CPA to better promote advocacy efforts that favor ecosystems and human and non-human animals. This can be done in two ways. First, given the aforementioned advantages for companies in terms of information provision and favor with government officials, companies can use their privileged position to advocate for the natural environment beyond their instrumental needs, and instead highlight the intrinsic value of selected species. Second, companies have a duty to ensure that citizens and ecological stakeholders are capably represented by qualified human agents (such as members of ecological groups) in the political process. These groups are oftentimes the "mouthpieces" of intrinsic environmental interests. Companies can sponsor research that shows where and how ecosystems can be preserved. They can also increase their transparency in sharing their own information with ecological groups, through activities such as facility tours, workshops, and multi-stakeholder forums. The goal is to give citizens and ecological groups a larger information base upon which they can present their voice to public officials, essentially mitigating some of the informational advantages of business interests in policymaking as described above. The intention is that public policies that emerge from this more inclusive process should much better promote ecological interests because government officials will have a greater range of information to make their policy decisions.

One shortcoming to these recommendations is the lack of independence, or at least the perceived lack of independence, of company-sponsored research activities conducted by citizens and environmental groups. A recent public health study reported that between 2011 and 2015, Coca-Cola and PepsiCo., Inc. sponsored nearly 100 health organizations to study the health effects of soft drinks, including the American Diabetes Association and the Juvenile Diabetes 
Research Foundation (Lauerman, 2016). If companies are to support the abilities of citizens and ecological groups to more effectively develop accurate and reliable informational bases to participate in the political process, these companies need to devise effective firewalls between themselves and their recipient organizations, as well as to keep such relationships transparent to the public. One solution might be to establish a "blind trust" where a company creates and funds a wholly independent entity that in turn directs funds towards human and ecological stakeholders to conduct research and promulgate their findings. The management of the blind trust would be independent of the management of the company, mitigating some of these conflicts of interests.

\section{CONCLUSION}

As recognized by scholars, since companies and their managers exercise many decisions about strategies and resource allocations towards the natural environment, such as the sustainable use of natural resources and the treatment of ecosystems and human and non-human animals, it is impossible to overlook the ethical foundations of such actions (Nelson \& Vucetich, 2012; Thompson, 2007). Yet, much scholarship about corporate sustainability management - under which we included EM, CSR and CPA - has primarily adopted an orientation towards ethics that (often implicitly) views sustainability as a means to an end and hence has an instrumental character. Our discussion showed that scholarship (and company practices) about corporate sustainability management is loaded with questions about the value and moral status of humans, non-humans, and ecosystems. Relevant discussions would profit from a more explicit acknowledgement of ethical orientations that stress the intrinsic value of sustainability. This is not to say that we should simply replace instrumental reasoning for more intrinsic reasoning; both are needed if we want to gain a comprehensive perspective on sustainable business 
practices. Rather, our review emphasized that corporate sustainability management can extend its ethical reach and be entwined with more empirical phenomena if the scope of ethical orientations is broadened to include more intrinsic reasoning. 


\section{REFERENCES}

Abbott, K. W. 2012. Engaging the Public and the Private in Global Sustainability Governance. International Affairs 88(3): 543-64.

Abney, K. 2004. Sustainability, Morality and Future Rights. Moebius, 2: 23-32.

Angelsen, A. 2011. The poverty-environment thesis: Was Brundtland wrong? Forum for Development Studies, 24(1): 135-154.

Anker, P., \& Witoszek, N. 1998. The dream of the biocentric community and the structure of utopias. Worldviews, 2: 239-56.

Arnold, D. G. 2016. Corporate responsibility, democracy, and climate change. Midwest Studies in Philosophy, 40(1): 252-261.

Audi, R. 2010. The place of ethical theory in business ethics. In G. G. Brenkert \& T. L. Beauchamp (Eds.), The Oxford Handbook of Business Ethics: 46-72. Oxford: Oxford University Press.

Bansal, P. 2005. Evolving sustainably: A longitudinal study of corporate sustainable development. Strategic Management Journal, 26: 197-218.

Barnett, M. L., \& Salomon, R. M. 2012. Does it pay to be really good? Addressing the shape of the relationship between social and financial performance. Strategic Management Journal, 33(11): 1304-1320.

Baron, D. 1995. Integrated strategy: Market and nonmarket components. California Management Review, 37(2)187-194.

Baumann-Pauly, D, Wickert, C., Spence, L. \& Scherer, A. G.. 2013. Organizing Corporate Social Responsibility in Small and Large Firms: Size Matters. Journal of Business Ethics 115(4): 693-705.

Berrone, P., Fosfuri, A., Gelabert, L., \& Gomez-Mejia, L. R. 2013. Necessity as the mother of 'green' inventions: Institutional pressures and environmental innovations. Strategic Management Journal, 34: 891-909.

Berry, J. 1999. The new liberalism: The rising power of citizen groups. Washington, DC: Brookings Institution Press. 
Bertels, S., Hoffman, A. J., \& DeJordy, R. 2014. The varied work of challenger movements: Identifying challenger roles in the US environmental movement. Organization Studies, 35(8): 1171-1210.

Blair, M.M. 2015. Of Corporations, Courts, Personhood, and Morality. Business Ethics Quarterly, 25(4): 415-431.

Bowie, N. 1991. New Directions in corporate social responsibility. Business Horizons, 34(4): $56-65$.

Bradley, B. 2006. Two concepts of intrinsic value. Ethical Theory and Moral Practice, 9: 11130.

Brennan, A., \& Lo, Y.-S. 2016. Environmental ethics. In E. N. Zalta (Ed.), The Stanford Encyclopedia of Philosophy (Fall 2016 Edition), Available at: http://plato.stanford.edu/archives/fall2016/entries/ethics-environmental

Carroll, A. B. 1979. A three-dimensional conceptual model of corporate performance. Academy of Management Review, 4: 497-505.

CDP. 2014. Major public companies describe climate-related risks and costs: $A$ review of findings from CDP 2011-2013 disclosures. https://www.cdp.net/en/reports/archive

Christensen, L. T., Morsing, M., \& Thyssen, O. 2017. License to critique: A communicationbased perspective on sustainability standards. Business Ethics Quarterly. Forthcoming.

Christiano, T. 2006. Democracy. Stanford Encyclopedia of Philosophy. http://plato.stanford.edu/entries/democracy/. Accessed August 25, 2016.

Clawson, D, Neustadtl A., \& Weller, M. 1998. Dollars and votes: How business campaign contributions subvert democracy. Philadelphia: Temple University Press.

Dahl, R. 1959. A preface to democratic theory. Chicago: University of Chicago Press.

Dahlmann, F., \& Grosvold, J. 2017. Environmental managers and institutional work: Reconciling tensions of competing institutional logics. Business Ethics Quarterly. Forthcoming.

Delmas, M., Etzion, D., \& Nairn-Birch, N. 2013. Triangulating environmental performance: What do corporate social responsibility ratings really capture? Academy of Management Perspectives, 27(3): 255-267.

DesJardins, J. 2007 Business, ethics, and the environment: Imagining a sustainable future. Upper Saddle River, NJ: Pearson Prentice Hall. 
DesJardins, J. 2016. Is it time to jump off the sustainability bandwagon? Business Ethics Quarterly, 26(1): 117-135.

Dobson, A. 1998. Justice and the environment: Conceptions of environmental sustainability and theories of distributive justice. Oxford/New York: Oxford University Press.

Donaldson, T., \& Preston, L. E. 1995. The stakeholder theory of the corporation: concepts, evidence, and implications. Academy of Management Review, 20(1): 65-91.

Elkington, J. 1998. Cannibals with forks: The triple bottom line of $21^{\text {sc }}$ century business. Gabriola Island, BC: New Society Publishers.

Ferraro, F., Etzion, D., \& Gehman, J. 2015. Tackling grand challenges pragmatically: Robust action revisited. Organization Studies, 36(3): 363-390.

Fiedler, P.L., \& Jain, S.K. (Eds.) 1992. Conservation biology: The theory and practice of nature conservation, preservation and management. New York/London: Chapman \& Hall.

Francione, G. L., \& A Carlton 2015. Animal rights: The abolitionist approach, Exempla Press.

Frank, D., Hironaka, A. and Schofer, E. 2000. The Nation-State And The Natural Environment Over The Twentieth Century. American Sociological Review 65(1): 96-116.

Fremeth, A. R., \& Richter, B. K. 2011. Profiting from environmental regulatory uncertainty: Integrated strategies for competitive advantage. California Management Review, 54: 145165.

Gardiner, S. M. \& Thompson, A. (Eds.) 2017. The Oxford handbook of environmental ethics. Oxford: Oxford University Press.

Garriga, E., \& Melé, D. 2004. Corporate social responsibility theories: Mapping the territory. Journal of Business Ethics, 53(1/2): 51-71.

Gelles, D. 2015. Unilever finds that shrinking its footprint is a giant task, New York Times. November 21. http://www.nytimes.com/2015/11/22/business/unilever-finds-that-shrinkingits-footprint-is-a-giant-task.html?_r=0, first accessed November 2016.

Gilbert, D. U, \& Rasche, A. 2007. Discourse ethics and social accountability: The ethics of SA 8000. Business Ethics Quarterly 17(2): 187-216.

Gilbert, D. U., Rasche, A., Waddock, S. 2011. Accountability in a global economy: The emergence of international accountability standards. Business Ethics Quarterly, 21(1): 2344. 
Gladwin, T. N., Kennelly, J. J., \& Krause, T.-S. 1995. Shifting paradigms for sustainable development: Implications for management theory and research. Academy of Management Review, 20(4): 874-907.

Grey, W. 1993. Anthropocentrism and deep ecology. Australasian Journal of Philosophy 71(4): 463-75.

Guha, R. 1989. Radical American environmentalism and wilderness preservation: A third world critique, Environmental Ethics, 11: 71-83.

Gunther, M. 2016. Nike and Levi's pile on for 'fast fashion' culture reform, Greenbiz. September 20. https://www.greenbiz.com/article/nike-and-levis-pile-fast-fashion-culture-reform, first accessed November 2016.

Haley, U., \& Schuler, D. A. 2011. Government policy and firm strategy in the solar photovoltaic industry: Implications for technology and production. California Management Review, 54 (1): 17-39.

Hart, S. L. 1995. A natural-resource-based view of the firm. Academy of Management Review, 20(4): 986-1014.

Hart, S. L., \& Sharma, S. 2004. Engaging fringe stakeholders for competitive imagination. Academy of Management Executive, 18(1): 7-18.

Hawken, P., Lovins, A., \& Lovins, L. H. 1999. Natural capitalism: Creating the next industrial revolution. Boston: Little Brown.

Hempel, L. C. 2012. Evolving concepts of sustainability in environmental policy. In M. E. Kraft \& S. Kamieniecki (Eds.), The Oxford handbook of U.S. environmental policy: 67-91. Oxford: Oxford University Press.

Henisz, W. J., Dorobantu S, \& Nartey L. J. 2014. Spinning gold: The financial returns to stakeholder engagement. Strategic Management Journal, 35(12): 1727-1748.

Henisz, W. J., \& Zelner, B. A. 2012. Strategy and competition in the market and nonmarket arenas. Academy of Management Perspectives, 26(3): 40-51.

Hillman, A. J. 2005. Politicians on boards of directors: Do connections affect the bottom line? Journal of Management, 31(3): 464-481.

Hoffman, A. J. 1999. Institutional evolution and change: Environmentalism and the U.S. chemical industry. Academy of Management Journal, 41(4): 351-371.

Hoffman, A. J. 2001. From heresy to dogma: An institutional history of corporate environmentalism. Stanford, CA: Stanford University Press. 
Hoffman, A. J., \& Jennings, P. D. 2015. Institutional theory and the natural environment: research in (and on) the anthropocene. Business \& Society, 28(1): 8-31.

Hoffman, W. M., Frederick, R., \& Petry, E.S. (Eds.) 1990 The corporation, ethics and the environment. New York: Quorum Books.

Jones, T, \& Felps, W. 2013. Shareholder Wealth Maximization and Social Welfare: A Utilitarian Critique. Business Ethics Quarterly 23(2): 207-38.

Kassinis, G., \& Vafeas, N. 2006. Stakeholder pressures and environmental performance. Academy of Management Journal, 49(1): 145-159.

King, A. A., \& Lenox, M. J. 2001. Lean and green? An empirical examination of the relationship between lean production and environmental performance. Production And Operations Management, 10(3): 244-256.

King, A. A., \& Lenox, M. J. 2002. Exploring the locus of profitable pollution reduction. Management Science, 48(2): 289-299.

Langhelle, O. 1999. Sustainable development: Exploring the ethics of our common future. International Political Science Review, 20(2): 129-149.

Langhelle, O. 2000. Sustainable development and social justice: Expanding the Rawlsian framework of global justice. Environmental Values, 9(3): 295-323.

Lauerman, K. 2016. Big Soda sponsored 96 health groups - a big conflict of interest, study says. Washington Post. October 10. https://www.washingtonpost.com/news/to-yourhealth/wp/2016/10/10/big-soda-sponsored-96-health-groups-a-big-conflict-of-intereststudy-says/, first accessed November 2016.

Lawrence, T. B., \& Suddaby, R. 2006. Institutions and institutional work: In S. R. Clegg, C. Hardy, T. B. Lawrence, \& W. R. Nord (Eds.), Handbook of organization studies (2nd ed): 215-254. London, UK: SAGE Publications.

Leopold, A. 1949. A sand county almanac and sketches here and there. Oxford: Oxford University Press.

Lindblom, C. 1977. Politics and markets: The world's political economic systems. New York: Basic Books.

Luke, T. W. 2002. Deep Ecology: Living as If Nature Mattered: Devall and Sessions on Defending the Earth. Organization \& Environment 15(2): 178-86.

Maguire, S., \& Hardy, C. 2009. Discourse and deinstitutionalization: The decline of DDT. Academy of Management Journal, 52(1): 148-178. 
McDonough, W. \& Braungart, M. 2002 Cradle to cradle: Remaking the way we make things, New York: North Point Press.

McDonough, W. \& Braungart, M. 2013. The upcycle: beyond sustainability-Designing for abundance, New York: North Point Press.

McKibben, B. 2015. Exxon's climate lie: No corporation has ever done anything this big or bad. The Guardian. Wednesday 14 October 2015, first accessed September 2016.

McShane, K. 2014. The Bearers of value in environmental ethics, in A. Hiller, R. Ilea and L. Kahn (eds.), Consequentialism and Environmental Ethics: 17-34. New York: Routledge.

McWilliams, A., \& Siegel, D. 2001. Corporate social responsibility: A theory of the firm perspective. Academy of Management Review, 26(1): 117-127.

Mill, J. S., 1861, Considerations on representative government. Buffalo, NY: Prometheus Books.

Mitchell, R. K., Agle, B. R., \& Wood, D. J. 1997. Toward a theory of stakeholder identification and salience: Defining the principle of who and what really counts. Academy of Management Review, 22(4): 853-886.

Næss, A., 1973. The shallow and the deep, long-range ecology movement, Inquiry, 16: 95-100.

Næss, A. 1989. Ecology, community, lifestyle. Cambridge: Cambridge University Press.

Nelson, M. P., \& Vucetich, J. A. 2012. Sustainability science: Ethical foundations and emerging challenges. Nature Education Knowledge. Retrieved from http://www.nature.com/scitable/knowledge/library/sustainability-science-ethicalfoundations-and-emerging-challenges-24319566

Neumeyer, E. 2003. Strong versus weak sustainability: Exploring the limits of two opposing paradigms ( $2^{\text {nd }}$ edition). Cheltenham, UK: Edward Elgar.

Newton, L. 2005. Business ethics and the natural environment. Malden, MA: Blackwell.

Newton, L. 2013. The American experience in environmental protection, New York: Springer.

Newton, L. \& Dillingham, C. 2002. Watersheds 3: Ten cases in environmental ethics. Belmont, CA: Wadsworth.

North, B. G. 1987. Conservation and preservation: A conceptual rehabilitation. Environmental Ethics, 8(3): 195-220.

Olson, M. 1971. The logic of collective action. Cambridge, MA: Harvard University Press. 
Orlitzky, M., Schmidt, F. L., \& Rynes, S. L. 2003. Corporate social and financial performance: A meta-analysis. Organization Studies, 24(3): 403-441.

Porter, M. E., \& Kramer, M. R. 2002. The competitive advantage of corporate philanthropy. Harvard Business Review, 80(12): 56-69.

Porter, M. E., \& Kramer, M. R. 2006. Strategy \& society: The link between competitive advantage and corporate social responsibility. Harvard Business Review, 84(12): 78-92.

Porter, M. E., \& Kramer, M. R. 2011. Creating shared value. Harvard Business Review, 89(1/2): $62-77$.

Porter, M. E., \& Van der Linde, C. 1995a. Green and competitive: Ending the stalemate. Harvard Business Review, 73(5): 120-134.

Porter, M. E., \& Van der Linde, C. 1995b. Toward a new conception of the environmentcompetitiveness relationship. Journal of Economic Perspectives, 9(4): 97-118.

Potoski, M., \& Prakash, A. 2005. Green clubs and voluntary governance: ISO 14001 and firms' regulatory compliance. American Journal of Political Science, 49(2): 235-248.

Prasad, P., \& Elmes, M. 2005. In the name of the practical: Unearthing the hegemony of pragmatics in the discourse of environmental management. Journal of Management Studies, 42(4): 845-867.

Rasche, A. 2015. The Corporation as a Political Actor - European and North American Perspectives. European Management Journal 33(1): 4-8.

Rasche, A. 2009. 'A Necessary Supplement' What the United Nations Global Compact Is and Is Not. Business \& Society 48(4): 511-37.

Rasche, A, \& Esser, D. E. 2006. From Stakeholder Management to Stakeholder Accountability. Journal of Business Ethics 65(3): 251-67.

Rockström, J. et al. 2009. A Safe Operating Space for Humanity, Nature 461(7263): 472-75.

Rogers, E. M. 2003. Diffusion of Innovations. ( $5^{\text {th }}$ ed.). New York: Free Press.

Roodman, D. M. 1998 The Natural Wealth of Nations: Harnessing the Market for the Environment. New York: Norton.

Rousseau, J. J. 1762. The social contract. (trans. Charles Frankel, 1947). New York: Hafner Publishing Co. 
Russo, M. V. 2010. Companies on a mission: Entrepreneurial strategies for growing sustainably, responsibly, and profitably. Stanford, CA: Stanford Business Books.

Russo, M. V., \& Fouts, P. A. 1997. A resource-based perspective on corporate environmental performance and profitability. Academy of Management Journal, 40(3): 534-559.

Sagoff, M. 2004. Price, Principle, and the Environment. New York: Cambridge University Press.

Sandhu, S., Ozanne, L. K., Smallman, C., \& Cullen, R. 2010. Consumer driven corporate environmentalism: Fact or fiction? Business Strategy and the Environment, 19: 356-366.

Sandler, R. 2012. Intrinsic Value, Ecology, and Conservation. Nature Education Knowledge $3(10)$.

Scherer, A. G., \& Palazzo, G. 2011. The new political role of business in a globalized world: A review of a new perspective on CSR and its implications for the firm, governance, and democracy. Journal of Management Studies, 48(4): 899-931.

Scherer, A. G., Rasche, A., Palazzo, G., \& Spicer, A. 2016. Managing for political corporate social responsibility: New challenges and directions for PCSR 2.0. Journal of Management Studies, 53(3): 273-298.

Schoeneborn, D. et al. 2014. The Three Schools of CCO Thinking: Interactive Dialogue and Systematic Comparison, Management Communication Quarterly 28(2): 285-316.

Schuler, D. A., Rehbein, K., \& Cramer. R. 2002. Pursuing strategic advantage through political means: A multivariate approach. Academy of Management Journal, 45: 659-672.

Scott, W. R. 2001. Institutions and organizations (2d ed.). Thousand Oaks, CA: Sage.

Sharfman, M. P., \& Fernando, C. S. 2008. Environmental risk management and the cost of capital, Strategic Management Journal, 29: 569-592.

Sharma, S. 2014. Competing for a Sustainable World: Building Capacity for Sustainable Innovation, Sheffield, UK: Greenleaf Publishing.

Sharma, S., \& Henriques, I. 2005. Stakeholder influences on sustainability practices in the Canadian forest products industry, Strategic Management Journal, 26: 159-180.

Sharma, S., \& Vredenburg, H. 1998. Proactive corporate environmental strategy and the development of competitively valuable organizational capabilities. Strategic Management Journal, 19: 729-753.

Singer, P. 1975. Animal Liberation. New York: Random House. 
Singer, P. 1993. Practical Ethics, (2 ${ }^{\text {nd }}$ Edition). Cambridge: Cambridge University Press.

Slawinski, N., \& Bansal, P. 2012. A matter of time: The temporal perspectives of organizational responses to climate change. Organization Studies, 33(11): 1537-1563.

Slawinski, N., \& Bansal, P. 2015. Short on time: Intertemporal tensions in business sustainability. Organization Science, 26(2): 531-549.

Starik, M. 1995. Should trees have managerial standing? Toward stakeholder status for nonhuman nature. Journal of Business Ethics, 14(3): 207-217.

Starik, M., \& Kanashiro, P.. 2013. Toward a Theory of Sustainability Management: Uncovering and Integrating the Nearly Obvious. Organization \& Environment, 26: 7-30.

Starik, M., \& Rands, G. P. 1995. Weaving an integrated web: Multilevel and multisystem perspectives of ecologically sustainable organizations. Academy of Management Review, 20(4): 908-935.

Sylvan, R. 1985. A Critique of Deep ecology, Radical Philosophy, 40: 2-12.

Taylor, P. 1981. The Ethics of Respect for Nature. Environmental Ethics, 3: 197-218.

Thompson, P. B. 2007. Agricultural sustainability: what it is and what it is not. International Journal of Agricultural Sustainability, 5(1): 5-16.

Velasquez, M. 1992. International business, morality and the common good. Business Ethics Quarterly, 2(1): 27-40.

Waddock, S. 2008. Corporate responsibility/corporate citizenship: The development of a construct. In A. G. Scherer \& G. Palazzo (Eds.), Handbook of research on global corporate citizenship: 50-73. Cheltenham: Edward Elgar.

Waddock, S. A., \& Graves, S. B. 1997. The corporate social performance - financial performance link. Strategic Management Journal, 18(4): 303-319.

Waldau, P. 2011 Animal Rights: What Everyone Needs to Know. New York: Oxford University Press.

West, W. F. 2009. Inside the black box: The development of proposed rules and the limits of procedural controls. Administration and Society, 41: 576-596.

Whiteman, G., Walker, B., \& Perego, P. 2013. Planetary boundaries: Ecological foundations for corporate sustainability. Journal of Management Studies, 50(2): 307-336. 
Wijen, F. 2014. Means versus ends in opaque institutional fields: Trading off compliance and achievement in sustainability standard adoption. Academy of Management Review, 39(3): $302-323$.

Windsor, D. 2006. Corporate social responsibility: Three key approaches. Journal of Management Studies, 43(1): 93-114.

World Commission on Environment and Development (WCED). 1987. Report of the World Commission on Environment and Development (UN General Assembly A/42/427, 4 August 1987). New York, NY: United Nations.

World Economic Forum. 2016. The Global Risks Report, 11th ed. Geneva: World Economic Forum.

Zink, T., \& Geyer, R. 2016. There is no such thing as a green product. Stanford Social Innovation Review (Spring). 
TABLES

Table 1: Key Orientations in Environmental Ethics

\begin{tabular}{|l|l|l|l|}
\hline \multicolumn{2}{|c|}{$\begin{array}{l}\text { Instrumental Value } \\
\text { (Few Limits on the Use } \\
\text { of the Natural World for } \\
\text { Human Needs) }\end{array}$} & $\begin{array}{l}\text { Intrinsic Value } \\
\text { (Few Limits on the } \\
\text { Obligations to Protect } \\
\text { the Natural World) }\end{array}$ \\
\hline $\begin{array}{l}\text { Sustainable Resource Use } \\
\text { Tumservation and }\end{array}$ & $\begin{array}{l}\text { Consep Ecology } \\
\text { Preservation }\end{array}$ & Rights-based Perspectives \\
\hline $\begin{array}{l}\text { We can use resources for } \\
\text { creating profit, but must do so } \\
\text { sustainably. The environment is } \\
\text { often seen as something to be } \\
\text { fairly distributed (justice } \\
\text { orientation). Non-sentient } \\
\text { objects of the environment hold } \\
\text { no intrinsic value (utilitarian } \\
\text { orientation). }\end{array}$ & $\begin{array}{l}\text { Conserve resources for later use } \\
\text { by humans out of self-interest } \\
\text { (conservation of environment } \\
\text { for instrumental reasons) } \\
\text { Protect an ecosystem because } \\
\text { there is an intrinsic value in it } \\
\text { (preservation of environment } \\
\text { because of its intrinsic value). }\end{array}$ & $\begin{array}{l}\text { Single species or also entire } \\
\text { ecosystems enjoy rights that } \\
\text { need to be respected (regardless } \\
\text { whether the consequences of an } \\
\text { action are good or bad). }\end{array}$ & $\begin{array}{l}\text { Humans fully depend on } \\
\text { nature; all livings things are } \\
\text { biospheric net; rejection of } \\
\text { dominating social structures of } \\
\text { any kind. }\end{array}$ \\
\hline $\begin{array}{l}\text { Angelsen (2011), Dobson } \\
\text { (1998), Singer (1993), }\end{array}$ & $\begin{array}{l}\text { North (1987), Neumeyer (2003, } \\
\text { Fiedler \& Jain (1992) }\end{array}$ & $\begin{array}{l}\text { Singer (1975), Francione \& } \\
\text { Carlton, (2015), Waldau, (2011) }\end{array}$ & $\begin{array}{l}\text { Næss (1973), Sylvan (1985), } \\
\text { Grey (1993) }\end{array}$ \\
\hline
\end{tabular}

